\title{
Effect of Demographic Factors on Organizational Citizenship Behavior: A Study at the Private Higher Education in Purwokerto Province of Central Java
}

\author{
Amin Budiastuti ${ }^{1)}$, Mutiasari ${ }^{2)}$, Susanti Budiastuti ${ }^{3)}$ \\ \{budiastutiamin@gmail.com ${ }^{1)}$, sarimutia09@yahoo.co.id ${ }^{2}$, susantibudiastuti02@gmail.com ${ }^{3)}$ \} \\ ${ }^{1,2,3)}$ Sekolah Tinggi Ilmu Ekonomi Satria Purwokerto
}

\begin{abstract}
The purpose of this research was to determine the effect of several demographic factors (age, gender, educational qualification, and years of experience) on organizational citizenship behavior of educational staffs at Private Higher Education in Purwokerto, Central Java Province. Participants were selected from 11 Private Higher Educations in Purwokerto. Number of samples were 150 educational staffs taking with the Slovin formula and determined by cluster random sampling method. Data were collected by distributing a questionnaire and it was analyzed using quantitative descriptive analysis and t-test. The results showed educational qualification and years of experience had a significant effect on Organizational Citizenship Behavior, however, gender and age had no significant effect.
\end{abstract}

Keywords: Demographic factors, Organizational Citizenship Behavior, Educational staffs

\section{Introduction}

Management of human resources is the most important factor in an organization especially when the challenges are more complex. A Private Higher Education is an organization facing major challenges related to future sustainability, especially from external environmental dynamics, such as increasingly stringent competitions, government policies and industry demands related to the competency of graduates. Educational staffs is a part of human resources at Private Higher Education which is tasked conducting administration, management, development, supervision, and technical services to support the education process. Educational staffs are required to have performance including a high organizational citizenship behaviour in working to achieve organizational objectives.

Organizational citizenship behavior has become a focus for many organizations because it can be used by managers in decision making. The attitude of conduct of employees is committed voluntarily, sincerely, happily without having to be ruled and controlled by the company in providing good service according to Organ et al. [1] known as organizational citizenship behavior (OCB). OCB is an individual's behavior that exceeds the job description in its task, doing work beyond its role in the organization that is beneficial to the interests of the organization and has a positive effect on the effectiveness of the organization, and in the long term affects the organization's survival. Individual behavior in the work place such as helping co-workers and courteous to others are the characters of OCB that employees shold have. OCB is very informal behaviors that is performed by employees, and exceed the required task and duties. 
Organizational citizenship behaviour does not appear on its own, but must be pursued through several factors. Organizational citizenship behaviour influenced by internal factors include the traits of one, attitudes, personality traits, physical properties, motivation, cultural background, age, gender, education, experience, and other personal variables, and external factors include factors that originate from the environment, leadership, co-worker actions, types of exercise and supervision, bonding work, wage system and environment. The benefits of OCB to the company are improving the productivity of co-workers, increasing managers' productivity, saving management's and organization's resources, saving energy resources to maintain the group function facilitating to coordinate the activities of the working groups, improving the ability of the organization to attract and to maintain the best employees, improving the stability of organizational performance, and enhancing the organization's ability to adapt environmental changes (Podsakoff et al.) [2]. It can be stated that if the company wants to increase employee's OCB, the company should pay attention to the factors influencing employee's OCB.

The research results on the effect of demographic factors on OCB have demonstrated significant influence (Cohen \& Avrahami) [3]. Based on the above explanations, the purpose of the research was to determine the effect of demographic factor on Organizational Citizenship Behavior. Accordingly, the research questions for this study were:

RQ1: Was there any effect of age on the Organizational Citizenship Behavior of educational staff at private higher educations in Purwokerto?

RQ2: Was there any effect of gender on Organizational Citizenship Behavior of educational staff at private higher educations in Purwokerto?

RQ3: Was there any effect of educational qualification on Organizational Citizenship Behavior of educational staff at private higher educations in Purwokerto?

RQ4: Was there any effect of years of experience on Organizational Citizenship Behavior of educational staff at private higher educations in Purwokerto?

\section{Literature Review}

\subsection{Organizational Citizenship Behavior}

According to Organs, Podsakoff, and MacKenzie [4] organizational citizenship behavior (OCB) is the freedom of individual behaviour, which is indirectly or explicitly acknowledged by the reward system, and contributes to the effectiveness and efficiency of organizational function.Organizational Citizenship Behavior (OCB) is work-related actions beyond the formal job description but appreciated by workplace, for the reason that it can boost the afficiency and achievability of organizational goal (Organ, 2006, cited in Batool) [5]. In other word, organizational citizenship behavior represents individual behavior that is discretionary, not directly or explicitly recognized by the formal reward system, and that in the aggregate promotes the effective functioning of the organization. OCB as an individual behavior that has freedom to do, indirectly or not is expelicitly recognized reward system, and gives benefit to the effectiveness and efficiency of organizational functions. OCB also defined more specifically as behaviors that contribute to or enhance the social and psychological context that support task performance.

Coyne and Ong [6] identified five dimensions of OCB: altruism, courtesy, sportsmanship conscientiousness, and civil virtue. Alturism focuses on behavior that is directly and 
intentionally aiming to help a specific individual or group of individuals. Courtesy activities aim to taking action in preventing problems by respecting other's needs. Sportsmanship activities are to try bearing a problem and avoid taking actions in handling a complaint. Conscientiousness focus carring out the role behaviors well beyond the minimum required.

\subsection{Demographic factors}

Demographic factors are variables extensively discussed inrelation to the organization such as organizational citizenship behavior. Demographic factors include age, gender, age, education level, and work period. The first demographic factor of Organizational Citizenship Behavior (OCB) is the gender. Rajput and Kochhar [7] studied the effect of demographics factor on several organizational variables in a sample of faculty member. Gender, age, occupation and type of organization affected responses with respect to motivation values and the intention to remain with the organization. Huang et al. [8] studied the interaction between age and OCB that resulted in younger employees performing higher OCB. However, older employees tended to engage in OCB for pro-social motives. In a sample of college students, females were more inclined to show OCB than males (LeBlanc) [9].

\section{Method}

Participants were selected from 11 Private Higher Educations in Purwokerto. Number of samples were 150 educational staffs who were taken with the Slovin formula which was determined by cluster random sampling method. This reseach was done descriptively using a survey method with questionnaire as a survey instrument. A self-developed questionnaire was used to obtain demographic data relevant to this study. Respondents were asked to provide information about demographic factors including age, gender, education qualification, and years of experience. Organizational citizenship behavior was measured used five dimension of OCB proposed by Organ, et al. (2006) as the most widely used in organizational related studies (Kittilertpaisane et al.) [10]. Five different dimentions namely, altruism, conscientiousness, sportsmanship, courtesy, civil virtue were measured using a 5 point scale by Likert. Data were analysed descriptively and $t$ test method.

First step validity and reliability analysis was conducted to check stability and consistency of measurement and the result showed that the instruments were valid and realible. Descriptive statistics included the mean score, standard deviation and other information about the OCB. Furthermore, the main analysis was to determine any statistically significant effect of demographic factors on the organizational citizenship behavior.

\section{Result And Discussion}

The results showed that gender of the respondent was $46 \%$ males and $54 \%$ females (Table 1). The age composition of the respondent consisted of $29 \%$ of $41-50$ years old, $27 \%$ of younger than 30 years, $27 \%$ of $31-40$ years old, and $17 \%$ of older than 50 years. Based on education qualification, as amount of $53 \%$ held under graduate degree, and $12 \%$ held post graduate degree $(12 \%)$. According to years of experience, $26 \%$ had less than 5 years of 
experience, $26 \%$ had less than 5 years of experiences, and $21 \%$ had more than 20 years of experience, $17 \%$ had $11-25$ years of experience, and $16 \%$ had $16-20$ years of experience.

Table 2 showed means score value of the five OCB dimensions. Civil virtue of educational staff having older than 50 years old (mean=4.47, $\mathrm{SD}=0.55$ ) had the highest mean. The following analysis results statistic Test $\mathrm{T}$. Based on the test formula $\mathrm{T}$, if $\mathrm{T}$ count the $>\mathrm{T}$ table and the value of the $<\alpha \mathrm{P}$, the result is declared influential significant. $\mathrm{T}$ table in this study was 1.96 .

To answer the first research question the effect of age on organizational citizenship behavior was explored. The result showed that age had no effect on organizational citizenship behavior $(\mathrm{p}>0.05)$. Based on the mean score values, civil virtue showed the highest score compared to the other organizational citizenship behavior dimensions. Educational staff aging above 50 years old had the highest value on civil virtue (Table 4).

Table 1. The demographic characteristics of the respondent

\begin{tabular}{cccc}
\hline Demographic & Groups & N & (\%) \\
\hline \multirow{4}{*}{ Age } & Below 30 & 41 & 27 \\
& $31-40$ & 40 & 27 \\
& $41-50$ & 43 & 29 \\
Gender & Above 50 & 26 & 17 \\
Education & Male & 69 & 46 \\
Qualification & Female & 81 & 54 \\
& HS & 20 & 13 \\
& D & 33 & 22 \\
& UG & 79 & 53 \\
Years Of & PG & 18 & 12 \\
Experience & Less Than 5 & 39 & 26 \\
& $5-10 \mathrm{yrs}$ & 30 & 20 \\
& $11-15$ yrs & 26 & 17 \\
& $16-20$ yrs & 24 & 16 \\
& $>20$ yrs & 31 & 21 \\
\hline
\end{tabular}

To answer the research question on the effect of age on organizational citizenship behavior was explored. As shown in Table 2, the significant value $=0.076$ and $\mathrm{t}$ calculation $=1.790(\mathrm{t}$ Table 1.960). It confirmed that age had no effect on organizational citizenship behavior ( $\mathrm{p}>$ 0.05).

As shown in Table 3, the significant value $=0.121$ and $\mathrm{t}$ calculation $=1.561$ ( $\mathrm{t}$ Table $1.960)$. It confirmed that gender had no effect on organizational citizenship behavior ( $p>$ $0.05)$.

Table 2. Effect of age on organizational citizenship behavior

\begin{tabular}{lccccc}
\hline $\begin{array}{c}\text { Organizational } \\
\text { Citizenship } \\
\text { Behavior }\end{array}$ & Age & Mean & SD & t & Probability \\
& Below 30 & 4.21 & 0.75 & & \\
Altruism & $31-40$ & 4.17 & 0.57 & & \\
& $41-50$ & 4.20 & 0.55 & & \\
Conscientiousness & Above 50 & 4.28 & 0.56 & & \\
& Below 30 & 3.39 & 0.77 & & \\
& $31-40$ & 3.57 & 0.68 & & \\
\hline
\end{tabular}




\begin{tabular}{lccccc}
\hline & Above 50 & 3.59 & 0.88 & 1.790 & 0.076 \\
Sportsmanship & Below 30 & 3.63 & 0.63 & & \\
& $31-40$ & 3.66 & 0.54 & & \\
& $41-50$ & 3.67 & 0.79 & & \\
Courtesy & Above 50 & 3.73 & 0.66 & & \\
& Below 30 & 3.94 & 0.65 & & \\
& $31-40$ & 3.96 & 0.50 & & \\
Civic Virtue & $41-50$ & 4.01 & 0.79 & & \\
& Above 50 & 4.07 & 0.55 & & \\
& Below 30 & 4.33 & 0.60 & & \\
& $31-40$ & 4.31 & 0.50 & & \\
& $41-50$ & 4.32 & 0.60 & & \\
\hline
\end{tabular}

Table 3. Effect of gender on organizational citizenship behavior

\begin{tabular}{lccccc}
\hline $\begin{array}{c}\text { Organizational } \\
\text { Citizenship } \\
\text { Behavior }\end{array}$ & Gender & Mean & SD & t & $\begin{array}{c}\text { Probabilit } \\
\text { y }\end{array}$ \\
\hline Alturism & Male & 4.01 & 0.71 & & \\
Conscientiousness & Female & 4.38 & 0.62 & & \\
& Male & 4.00 & 0.68 & & \\
Sportsmanship & Female & 3.87 & 0.73 & & \\
& Male & 3.85 & 0.70 & 1.561 & 0.121 \\
Courtesy & Female & 3.94 & 0.61 & & \\
& Male & 4.13 & 0.52 & & \\
Civic Virtue & Female & 4,11 & 0.53 & & \\
& Male & 3.90 & 0.84 & & \\
\hline
\end{tabular}

To answer the research question of the effect of educational qualification on organizational citizenship behavior was explored. As shown in Table 4 , the significant value $=0.003$ and $t$ calculation $=3.066$ (t Table 1.960). It confirmed that educational qualification significantly effected to organizational citizenship behavior $(\mathrm{p}<0.05)$.

The dimensions of altruism, conscientiousness, courtesy, and civil virtue resulted in high mean score values for educational staff having more than 20 years experience and the sportsmanship dimension showing high mean score values was educational staff having 11 - 15 years of experience.

To answer the fourth research question the effect of years of experience on organizational citizenship behavior was explored. As shown in Table 5, the signficant value $=0.010$ and $\mathrm{t}$ calculation $=2.611(\mathrm{t}$ Table 1.960). It confirmed that the years of experience significantly affected to the organizational citizenship behavior $(\mathrm{p}<0.05)$.

Table 4. Effect of education qualification on organizational citizenship behavior

\begin{tabular}{cccccc}
\hline $\begin{array}{c}\text { Organizational } \\
\text { Citizenship } \\
\text { Behavior }\end{array}$ & $\begin{array}{c}\text { Education } \\
\text { Qualification }\end{array}$ & Mean & SD & t & Probability \\
\hline \multirow{3}{*}{ Altruism } & HS & 4.00 & 0.32 & \\
& D & 4.15 & 0.44 & \\
& UG & 4.34 & 0.61 & \\
& PG & 4.36 & 0.59 &
\end{tabular}




\begin{tabular}{|c|c|c|c|c|c|}
\hline & HS & 3.50 & 0.60 & & \\
\hline & $\mathrm{D}$ & 3.50 & 0.71 & & \\
\hline \multirow[t]{3}{*}{ Conscientiousness } & UG & 3.73 & 0.65 & 3.066 & 0.003 \\
\hline & PG & 3.78 & 0.63 & & \\
\hline & HS & 3.65 & 0.48 & & \\
\hline \multirow{4}{*}{ Sportsmanship } & $\mathrm{D}$ & 3.78 & 0.65 & & \\
\hline & UG & 4.01 & 0.51 & & \\
\hline & PG & 4.05 & 0.53 & & \\
\hline & HS & 2.85 & 0.67 & & \\
\hline \multirow[t]{4}{*}{ Courtesy } & $\mathrm{D}$ & 3.37 & 0.75 & & \\
\hline & UG & 3.60 & 0.79 & & \\
\hline & PG & 3.78 & 0.78 & & \\
\hline & HS & 4.05 & 0.39 & & \\
\hline \multirow{3}{*}{ Civic Virtue } & $\mathrm{D}$ & 4.42 & 0.50 & & \\
\hline & UG & 4.39 & 0.51 & & \\
\hline & PG & 4.43 & 0.60 & & \\
\hline
\end{tabular}

Table 5. Effect of year of experince on organizational citizenship behavior

\begin{tabular}{|c|c|c|c|c|c|}
\hline $\begin{array}{c}\text { Organizational } \\
\text { Citizenship } \\
\text { Behavior } \\
\end{array}$ & Year of Experience & Mean & $\mathrm{SD}$ & $\mathrm{t}$ & Probability \\
\hline \multirow{5}{*}{ Altruism } & Less than 5 years & 3.56 & 0.86 & & \\
\hline & $5-10 \mathrm{yrs}$ & 3.71 & 0.56 & & \\
\hline & $11-15 \mathrm{yrs}$ & 3.46 & 0.73 & & \\
\hline & $16-20 \mathrm{yrs}$ & 3.91 & 0.70 & & \\
\hline & More than 20 years & 4.02 & 0.92 & & \\
\hline \multirow{5}{*}{ Conscientiousness } & Less than 5 years & 3.90 & 0.58 & & \\
\hline & $5-10 \mathrm{yrs}$ & 3.99 & 0.77 & 2.611 & 0.010 \\
\hline & $11-15 \mathrm{yrs}$ & 3.90 & 0.66 & & \\
\hline & $16-20 \mathrm{yrs}$ & 3.93 & 0.64 & & \\
\hline & More than 20 years & 4.00 & 0.51 & & \\
\hline \multirow{5}{*}{ Sportsmanship } & Less than 5 years & 9.32 & 0.41 & & \\
\hline & $5-10 \mathrm{yrs}$ & 3.70 & 0.63 & & \\
\hline & $11-15 \mathrm{yrs}$ & 4.50 & 0.50 & & \\
\hline & $16-20 \mathrm{yrs}$ & 3.64 & 0.70 & & \\
\hline & More than 20 years & 4.48 & 0.56 & & \\
\hline \multirow{5}{*}{ Courtesy } & Less than 5 years & 3.70 & 0.78 & & \\
\hline & $5-10$ yrs & 3.87 & 0.69 & & \\
\hline & $11-15 \mathrm{yrs}$ & 3.56 & 0.56 & & \\
\hline & $16-20 \mathrm{yrs}$ & 3.97 & 0.57 & & \\
\hline & More than 20 years & 4.12 & 0.80 & & \\
\hline \multirow{5}{*}{ Civic Virtue } & Less than 5 years & 4.16 & 0.65 & & \\
\hline & $5-10$ yrs & 4.22 & 0.55 & & \\
\hline & $11-15$ yrs & 4.23 & 0.56 & & \\
\hline & $16-20 \mathrm{yrs}$ & 3.98 & 0.90 & & \\
\hline & More than 20 years & 4.28 & 0.51 & & \\
\hline
\end{tabular}




\section{Conclusion}

The average score of the five dimensions organizational citizenship behavior of educational staff based on demographic factor showed that participants response were high. Educational qualification and years of experience significantly affected to organizational citizenship behavior, while age and gender had no effect. This finding indicated that helping among educational staff tended to high. Educational staff having higher educational qualification and high years experience resulted in high organizational citizenship behavior.

Regarding the limitations and finding of the study, more studies need to be conducted as the following topics. This research was as initial finding in the private higher educations in Purwokerto. The collected data were in small number of respondents, replication of similar study in other types of employees and organization will help the management in determining the result and generality of present study. This study suggested that management should encourage personal to build attitudes such as organizational citizenship behavior.

\section{References}

[1] Organ, Dennis W., et al.: Organizational Citizenship Behavior, Its Nature, Antecedents, and Cosequences: Sage Publication, Inc. (2006).

[2] Podsakoff, P., MacKenzie, S., Paine, J., and Bachrach, D.: Organizational citizenship behaviors: A critical review of the theoretical and empirical literature and suggestions for future research. Journal of Management, 26(3), pp. 513-563 (2000).

[3] Cohen, A., \& Avrahami, A. The relationship between individualism, collectivism, the perception of justice, demographic characteristics and organisational citizenship behaviour. Service Industries Journal, 26(8), pp. 889-901 (2006).

[4] Podsakoff, P., MacKenzie, S., Paine, J., and Bachrach, D.: Organizational citizenship behaviors: A critical review of the theoretical and empirical literature and suggestions for future research. Journal of Management, 26(3), pp. 513-563 (2000).

[5] Batool, S.: Developing organization commitment and organizational justice to amplify organizational citizenship behavior in banking sector. Pakistan Journal of Commerce and Social Science, 7(3), pp. 646-655 (2003).

[6] Coyne, I. \& Ong, T.: Organization Citizenship behavior and turnover intention: A cross-cultural study. International Journal of Human Resource Management, 18(6), pp. 1085-1097 (2007).

[7] Rajput, N. \& Cochhar, R.: Demographic factors: Organizational culture in the academic institution. SCMS Journal of Indian Management, 11 (3), pp.51-63 (2014).

[8] Huang, Y., McDowell, J. \& Vargas, P.: How old I feel matters: Examining age-related differences in motives and organizational citizenship behavior. Journal of Park and Recreation Administration, 33 (1), 20-39. (2015).

[9] LeBlanc, C. J.: Characteristics sharping college student organizational citizenship behavior. American Journal of Business Education, 7(2), pp. 99-108 (2014).

[10] Kittilertpaisane, J., Chanchiprecha, C., Phoonkasem, C., Maneekhiaw, I., Niljinda, S., Khaosrijan, K., Akkara, W., Thularate, N., \& Karnsomdee, P.: Demographic Factors Affecting Organizational Citizenship Behavior in one Sub-District Administrative Organization in Phanna Nikhom District, Sakon Nakhon Province. Runirac Iv.pp. 344-352 (2011). 